\title{
Implementation of DSN-MUI Fatwa In Handling of Sharia Economic Problems (A Case In Syariah Bank of Bandar Lampung)
}

\author{
Khairuddin Tahmid ${ }^{1}$, Muhammad Zaki ${ }^{2}$, Haryanto $\mathrm{H}^{3}$
}

\begin{abstract}
Implementation of DSN-MUI Fatwa In Handling of Sharia Economic Problems (A Case In Syariab Bank of Bandar Lampung). This study aims to reveal the position of the fatwa of the National Sharia Board of the Indonesian Ulema Council (DSN-MUI) in the national legal system as well as to learn how it is applied in the Syariah Bank of Bandar Lampung. The DSN-MUI fatwa was issued to avoid the different provisions made by the Sharia Supervisory Board (DPS) in each Islamic financial institution. With the DSN MUI fatwa, the provisions for all sharia economic actors will be the same. This research found that the DSN MUI fatwa was not fully implemented in the activities carried out by the Syariah Bank of Bandar Lampung. Whereas, in the national legal system, the DSN MUI fatwa is considered as part of positive law and has become a law in concreto for judges and arbitrators in Basyarnas. Therefore it is imperative that all sharia financial institutions to fully implement all the existing provisions, not just in part.
\end{abstract}

Keywords: DSN MUI Fatwa, Syariah Bank of Bandar Lampung, Islamic economic law

\begin{abstract}
Abstrak: Implementasi Fatwa DSN-MUI dalam Penanganan Masalab Ekonomi Syariah (Studi Pada Bank Syariab Bandar Lampung). Penelitian ini bertujuan untuk mengungkap bagaimana kedudukan fatwa Dewan Syariah Nasional Majelis Ulama Indonesia (DSN-MUI) dalam sistem hukum nasional sekaligus mempelajari bagaimana penerapannya di Bank Syariah Bandar Lampung. Fatwa DSN-MUI dikeluarkan untuk menghindari adanya berbedaan ketentuan yang dibuat oleh Dewan Pengawas Syariah (DPS) pada masing-masing lembaga keuangan syariah. Dengan adanya fatwa DSN MUI, ketentuan untuk semua pelaku ekonomi syariah akan sama sehingga dapat menciptakan ketertiban hukum. Penelitian ini menemukan fakta bahwa fatwa DSN MUI belum sepenuhnya diterapkan dalam kegiatan yang dilaksanakan oleh Bank Syariah Bandar Lampung. Padahal, dalam sistem hukum nasional, fatwa DSN MUI berkedudukan sebagai bagian dari hukum positif dan telah menjadi hukum in concreto bagi hakim dan para arbriter di Basyarnas. Oleh karena itu sudah selayaknya semua lembaga keuangan syari'ah melaksanakan secara utuh semua ketentuan-ketentuan yang ada, tidak hanya sebagian saja.
\end{abstract}

Kata Kunci: Fatwa DSN MUI, Bank Syariah Bandar Lampung, hukum ekonomi Syariah.

\footnotetext{
1,2,3Sharia Faculty, Universitas Islam Negeri Raden Intan Lampung, Indonesia. Jl. H Endro Suratmin Sukarame Bandar Lampung, Indonesia

E-mail: ${ }^{1}$ khairuddin@radenintan.ac.id, ${ }^{2}$ muhammadzaki@radenintan.ac.id, ${ }^{3}$ haryantoh@radenintan.ac.id
} 


\section{Introduction}

Along with the rapid development of the Islamic economy in Indonesia, the Indonesian Ulema Council (MUI) added a new instrument in its organizational structure, the National Sharia Board (DSN). This institution was established specifically to deal with issues related to the activities of Islamic Financial Institutions (LKS). With the establishment of the National Sharia Board, hereinafter known as DSN-MUI, the MUI has three fatwa making and setting institutions namely: (1) Fatwa Commission, (2) Institute for Food, Drug, Beverage and Cosmetics) Study (LPPOM, and (3) National Sharia Board (DSN). ${ }^{1}$ The main function of this new institution is as an authority providing fatwa on sharia economics in Indonesia, whose organizational position is under the Indonesian Ulema Council.

The idea to establish a National Sharia Board (DSN) first emerged when the Central MUI held a workshop on Sharia Mutual Funds on July 29-30, 1997. Among the recommendations made, one was the desire to form a National Sharia Board. The recommendation was followed up with the issuance of MUI Decree No. Kep-754 / MUI / I1 / 1999 dated February 10, 1999, concerning the establishment of the National Sharia Council (DSN). ${ }^{2}$ The presence of DSN that year coincided with the formation of the Sharia Development Expert Committee at Sharia Banks. ${ }^{3}$

The National Sharia Board (DSN) is an institution under the Indonesian Ulema Council (MUI) consisting of legal experts (fuqoha) as well as experts and practitioners of sharia economics, especially the financial sector, both banks, and non-banks. Members of the National Sharia Board consist of scholars, practitioners, and experts in fields related to sharia muamalah. Members of the National Sharia Council

${ }^{1}$ Wahiduddinn Adam, Fatwa Majelis Ulama Indonesia (MUI) dalam Perspektif Hukum dan Perundang-Undangan (Badan Litbang Dan Diklat Kementerian Agama RI, 2012), p. 273.

${ }^{2}$ Laurence W. Friedmen, Teori dan Filsafat Hukum: Idealisme Filosofis dan Problematika Keadilan (Sususan II ), trans. by Muhammad Arifin (Jakarta: PT. Raja Grafindo Persada, 1994).p. 19.

${ }^{3}$ Khotibul Umam, 'Legalisasi Fikih Ekonomi Perbankan: Sinkronisasi Peran Dewan Syariah Nasional dan Komite Perbankan Syariah', Mimbar Hukum, 24.2 (2012): 360. 
are appointed by the MUI for a term of 4 years. ${ }^{4}$

The main tasks of the DSN-MUI include exploring, studying and formulating the values and principles of Islamic law (Shariah) in the field of iqtishädiyah through the establishment of fatwas to be used as guidelines in transaction activities in syari'ah financial institutions. DSNMUI also has the task of overseeing the implementation of the fatwas in Islamic Financial Institutions (LKS) through the Sharia Supervisory Board (DPS), which is an extension of DSN-MUI in Islamic financial institutions. ${ }^{5}$

The National Sharia Council also helps related parties, such as the Ministry of Finance, Bank of Indonesia, and other institutions in drafting regulations/provisions for Islamic financial institutions. In carrying out these duties and functions, the National Sharia Board (DSN) has a composition of plenary members consisting of sharia experts and economics/finance experts who have in-depth knowledge of sharia economics. In some circumstances, DSN can also involve partner institutions such as the Indonesian Institute of Accountants and Bank of Indonesia.

Based on the decision of the National Sharia Council Number 01 of 2000 regarding the Basic Guidelines of the National Sharia Board (PD DSN-MUI), the National Sharia Board (DSN), formed by the Indonesian Ulema Council with the task of overseeing and directing Islamic financial institutions to encourage the application of values Islamic teachings in economic and financial activities. The National Sharia Board is expected to play a proactive role in responding to the dynamic development of Indonesian society in the economic and financial fields.

Even though the presence of the Sharia Supervisory Board (DPS) has existed before the National Sharia Board (DSN), it does not mean that the DPS function is then abandoned, especially in the implementation of DSN tasks. The National Sharia Board continues to partner with DPS

${ }^{4}$ Ahmad Ifham, Ini Lho Bank Syariah - Memahami Bank Syariah dengan Mudah (Jakarta: Gramedia Pustaka Utama, 2015), p. 6.

${ }^{5}$ Hanif Luthfi, 'Fath Adz-Dzari'ah dan Aplikasinya dalam Fatwa Majelis Ulama Indonesia' (Institut Ilmu Quran Jakarta, 2007), p. 135. 
in supervising the implementation of sharia in each Sharia Financial Institution (LKS). For this reason, DSN has a duty and authority which has been given to it based on the Decree of the National Sharia Board of the Indonesian Ulema Council No. 01 of 2000. ${ }^{6}$

The DSN tasks referred to are as follows; (1) fostering the application of sharia values in economic activities, in general, and finance, in particular; (2) issuing fatwas on types of financial activities; (3) issuing fatwas on sharia financial products and services; and (4) supervising the application of the fatwa that has been issued. ${ }^{7}$

In its operations, DSN is authorized to do the following things, namely: (1) issuing fatwa that binds the DPS in each Islamic financial institution and becomes the basis for legal action of the related parties; (2) issuing fatwas which form the basis for provisions/regulations issued by authorized institutions such as the Ministry of Finance and Bank of Indonesia; (3) providing recommendations and/or revoking recommendations for names that will sit on the Sharia Supervisory Board of an Islamic financial institution; (4) inviting experts to explain a problem needed in the discussion of sharia economics, including domestic and foreign monetary authorities/financial institutions; (5) provides a warning to Islamic financial institutions to stop deviations from the fatwa that has been issued by the National Sharia Board; and (6) propose to the authorized agency to take action if the warning is not heeded. ${ }^{8}$

DSN fatwas are not only about the activities, products, and services of a sharia bank, but also other sharia economic activities including sharia accounting, sharia insurance, sharia pawnshops, sharia capital markets, and sharia financing. Each of these activities is regulated by a separate rule that directly or indirectly links the DSN-MUI fatwa. ' In many cases, the fatwas often become the basis for the provisions/regulations issued by certain institutions, such as the Ministry of Finance and Bank

\footnotetext{
${ }^{6}$ Hanif Luthfi.

${ }^{7}$ Hanif Luthfi, p. 13.

${ }^{8}$ Hanif Luthfi, p. 14.

${ }^{9}$ Wahiduddinn Adam, p. 274.
} 
of Indonesia (BI), especially in the field of Islamic capital markets and Islamic insurance. ${ }^{10}$

This article tries to answer two questions: (1) what is the position of the DSN-MUI Fatwa on Islamic economics in the National Law system? (2) has the DSN-MUI fatwa been fully implemented by the Islamic Financial Institution in Bandar Lampung? These two things will be the focus of this study.

\section{Position and Function of MUI DSN Fatwa}

To find out whether the MUI fatwa has a legal status can be seen from the fact whether the fatwa is used as a legal basis or not, and whether the parties that have a relationship with the contents of the fatwa are bound to implement it or not.

Broadly speaking, MUI fatwas can be divided into 3 (three) categories, namely fatwas relating to Islamic economics, fatwas on halal products, and fatwas on social issues. Of these three categories, the DSNMUI fatwa on sharia economics has a stronger position compared to the other two categories. This is indicated by the fact that DSN-MUI fatwas are not only a guideline for Bank of Indonesia, (BI) Financial Services Authority (OJK), and the Ministry of Finance in regulating Sharia Financial Institutions (LKS) conducting business activities based on the principles sharia, but it also serves as a guideline for judges in the Religious Courts for the settlement of cases in the field of sharia economics. ${ }^{11}$

In the field of sharia economics, the government, in this case, Bank of Indonesia (BI), the Financial Services Authority (OJK), and the Ministry of Finance, regulates that sharia products or business activities must obtain prior approval from the MUI in the form of a DSN-MUI fatwa. The DSN-MUI fatwa serves as a guideline or basis for the legality of sharia banking activities, sharia capital markets, and sharia insurance.

${ }^{10}$ DSN-MUI Decree No. 01 Th. 2000 concerning Basic Guidelines for DSN-MUI Part IV and DSN-MUI Decree No. 02 of 2000 concerning DSN-MUI Household Guidelines Article 1.

${ }^{11}$ Siti Rochmiyatun, Yusida Fitriyati, 'Implementation of Arrangements for Ikrar Wakaf Land (AIW) in The Indonesian Waqf Law (Case in Palembang City)', Al-'Adalah, 16.1 (2019). 
On the other hand, the Amendment of Law No.7 of 1989 concerning Religious Courts became Law No. 3 of 2006 in which Article 49 provides for the expansion of the absolute competence of the Religious Courts in the form of the authority to examine, decide upon, and settle matters in the field of sharia economics within the Syariah banking institutions, which include: Islamic banks, Islamic microfinance institutions, Islamic insurance, Islamic reinsurance, Islamic mutual funds, Islamic bonds and Islamic mid-term securities, Islamic securities, Islamic financing, Islamic pawnshops, pension funds, LKS, and Islamic business. ${ }^{12}$ As a follow-up to the expansion of its authority, the Judge in the Religious Court before deciding on Islamic economic matters will pay attention to the existing fatwas as it is determined that the judge must refer to the DSN fatwa. From the description above it appears that the DSN-MUI fatwas have a semi-formal position in the legislation, on account that although legally formal the MUI fatwa does not enter into the hierarchy of statutory regulations, but in the stages of implementing the laws and regulations are dependent on and guided by fatwas issued by the institution. So it can be said that the DSN-MUI fatwa is a rule of law in sharia economic activities, whose existence has a strong authority and is recognized by the laws and regulations in Indonesia. ${ }^{13}$ So, if there are parties related to this regulation not implementing the contents of the fatwa, they will get administrative sanctions from the Government.

This treatment is different from fatwas outside the field of Islamic economics. Here, there is no obligation for judges to use fatwa as a basis for legal considerations because no specific provisions are governing the matter. In the fatwas on halal products, for example, although it becomes the basis for the issuance of the halal label of a product, it does not have any legal sanctions if the manufacturer does not include the label on the

${ }^{12}$ Previously, Article 49 of Law No. 7. 1989 regarding the Religious Courts determined that the Religious Courts were only authorized to examine, decide upon and settle cases in the field of marriage; inheritance, wills, and grants carried out based on Islamic law; endowments and alms. The authority of the Religious Courts in settling cases in these fields is not removed by an amendment to Article 49 of Law No. 3 years. 2006, but only added to the authority to settle cases in the field of Islamic economics.

13 Siti Mahmudah, 'The Contextualization of Sharia and Its Contribution to The Development Of The Indonesian National Law', Al-Adalah, 16.1, 2019. 
product. ${ }^{14}$ The legal sanctions can be given only if the halal label issued does not comply with the MUI halal fatwa. ${ }^{15}$ The same thing applies to social life fatwas. Here, there is no requirement that MUI fatwas become the basis of regulation. Therefore, there are no sanctions can be imposed on those who commit acts contrary to the MUI fatwa. ${ }^{16}$

\section{Scope and Procedure of Establishing DSN Fatwa}

\section{A. Scope}

DSN is an institution under the MUI organization. Therefore, all procedures for determining fatwa, especially those relating to the istinbāth (legal finding method), cannot be separated from the methods dan procedures

${ }^{14}$ Article 30 of Law No.7 Year 1996 concerning Food stipulates that every person who manufactures or imports into Indonesian territory a food product that is packaged for trading must include a label on, inside, and or on food packaging. One of the mandatory labels is to contain information about halal. In the Elucidation of Article 30, it is stated that a new halal statement becomes an obligation if everyone who produces food and/or enters food into Indonesian territory to be traded, to declare that the food in question is halal for Muslims. The same provisions are also regulated in Law No. 23 of 1992 concerning Health Article 21. This is also strengthened by the provisions of Article 8 paragraph (1) of Law no. 8 of 1999 concerning Consumer Protection which stipulates that businesses are prohibited from producing and/or trading goods and/or services that do not comply with the provisions of the word "halal" on food labels as stipulated in the Decree of the Minister of Health of the Republic of Indonesia No. 82/Menkes/SK/I/1996 concerning the Inclusion of "Halal" on Food Labels and the Decree of the Minister of Health of the Republic of Indonesia No.924/Menkes/SK/VIII/1996, as well as the Decree of the Director-General of POM No.HK.00.06.3.00568 concerning the Procedures for Halal on the Food Label. Inclusion of the word "halal" on food labels must go through inspection and evaluation procedures by a team consisting of the Ministry of Health, the Ministry of Religion and the MUI. The results of the team's assessment were given to the MUI Fatwa Commission for its fatwa. If the fatwa states that the food or drink is halal, MUI immediately issues a Halal Certificate. Based on the Halal Certificate from the MUI, the Director-General of POM (Food, Drugs, and Beverage) subsequently approved the inclusion of "halal" on the food label. In Article 11 PP No. 69 of 1999 concerning Food Labels and Advertisements also stipulated that halal statements on food labels must be supported by the truth of the examination whose procedures were determined by the Minister of Religion with due regard to the considerations and suggestions of competent religious institutions. The competent religious institution referred to in the Elucidation of Article 11 is the MUI.

${ }^{15}$ If the producer does not include a label on his food or drink or includes a statement or statement that is incorrect on the label, including information on halal, he can be sentenced to a maximum imprisonment of three years and or a maximum fine of Rp.360,000,000.00 (three hundred sixty million rupiah), as stipulated in Article 58 of Law No.7 of 1996 concerning Food.

${ }^{16}$ Supreme Court Decision No. 1400K/Pdt/1986 granted the request of Andi Vonny Gani P. (Muslim) and Andrianus Petrus Hendrik Nelwan (non-Muslim) to get married. The case decided by the Supreme Court in 1986 contradicts the 1980 MUI Fatwa on Mixed Marriage which forbids the marriage of Muslim women with non-Muslim men. 
of istinbāth used by the MUI fatwa commission. ${ }^{17}$ The difference between the DSN fatwa and the MUI fatwa is only in the scope and theme of the fatwa. The scope and theme of the MUI fatwa cover all religious issues, ranging from religious, social, to scientific and technological issues; While the DSN fatwa is limited to the economic sector and activities of the Sharia Financial Institution (LKS) only. Sharia economic activities in question include; Sharia Banking, Sharia Insurance, Sharia Capital Market, Sharia Pawnshop, Sharia Accounting, Sharia MLM and Sharia Commodity Market. This is following the Decree of the National Sharia Council of the Indonesian Ulema Council No. 01 of 2000. The decree mentions the duties and authority of DSN-MUI, among others, to issue fatwas on types of financial activities and Islamic financial products/services. ${ }^{18}$

\section{B. Procedure in issuing DSN Fatwa}

Related to procedural issues in issuing fatwas on sharia economics, the National Sharia Council of the Indonesian Ulema Council (DSN-MUI) always follows the guidelines set by the MUI fatwa commission. The MUI ijtihad rules and provisions themselves are contained in "the Guidelines for the Determination of Fatwa" in 1986, ${ }^{19}$ which then, in 1997, was replaced with "the Guidelines for Determining the Fatwa of the Indonesian Ulema Council". 20 Following the mandate of the National Conference VI in 2000, this guideline was then revised in 2001 that became "Guidelines and Procedures for the Determination of the Fatwa of the Indonesian Ulema Council", ${ }^{21}$ with several improvements, including the nature of the determination of the fatwa which is supposed to be responsive, proactive, and anticipatory." 22

${ }^{17}$ Himpunan Fatwa Keuangan Syariah Dewan Syariah Nasional MUI, p. 26.

${ }^{18}$ Himpunan Fatwa Keuangan Syariah Dewan Syariah Nasional MUI (Jakarta: Erlangga, 2014), p. 13.

19 The results of the decision of the Indonesian Ulema Council Plenary Session on 7 Jumadil Awwal 1406 H./18 January 1986 M.

${ }^{20}$ Decree of the Indonesian Ulema Council Leadership Council number: U-596/ MUI/X/1997 dated October 2, 1997.

${ }^{21}$ Keputusan Rapat Komisi Fatwa, 23 Muharram 1422/12 April 2001.

22 Refer to the Guidelines and Procedure for the Determination of Fatwa of the Ulema Council, Jakarta, MUI Secretariat, 2001 in paragraph 2 of Chapter II regarding the general basis for the determination of the fatwa. 
In 2006, the Fatwa Commission, through Ijtima Ulamā II of the Indonesian Fatwa Commission in Gontor, Ponorogo, produced a decree in the form of a fatwa regarding the unification of mindset in religious matters (taswiyah al-manhaj). The formulation of the decree covers the following matters: ${ }^{23}$

1. Differences of opinion that occur among Muslims is a natural, as a consequence of the institution of "ijtihâd" that allows differences.

2. The attitude of considering his own opinion is the most correct and tending to blame other opinions, including rejecting dialogue, is an anâniyyah (egoism) and 'ashâbiyyah hizbiyyah (group fanaticism) attitude that is contrary to the principle of tolerance (al-tasamuh), and has the potential to result in mutual animosity (al-'adāwah), contention (al-tanāzu'), and division (al-insyiqāq).

3. Differences of opinion among Muslims must not be interpreted as unlimited freedom (bil hudūd wa bil dhawäbith).

4. The difference that can be tolerated is the difference in the majal al-ikhtiläf (region of difference). Whereas the differences that are outside are not categorized as differences, but rather as deviations; like the difference to a problem that is certain (ma'lüm min al-din bi al-dlarūrah).

5. In addressing the problems of differences that enter the al-Ikhtiläf majall it should be sought by finding a common ground to get out of differences (al-khurüj min al-khiläf) and as much as possible to find similarities.

6. Majäl al-ikhtiläf is an area of thought that is still in the corridor ma ana 'alaihi wa ashhäbi, namely the Ahlussunnah wal Jamaah religious understanding in a broad sense.

In further developments, this guideline was refined through the Ijtima 'Ulama forum of the Indonesian Fatwa Commission, which was then refined again at the 8th National Conference of the Indonesian Ulema Council on 16 Sya'ban $1431 \mathrm{H}$ to coincide with July 28, 2010, in Jakarta. ${ }^{24}$

${ }^{23}$ The decision of Ijtima Ulama of the Indonesian Fatwa Commission II in 2006, Jakarta, MUS Secretariat, 2006, concerning the Asailyyah Wathäniyyah Masäil, a section on equating thought patterns in religious matters (taswiyah al-manhaj).

${ }^{24}$ Hanif Luthfi, p. 135. 


\section{Istinbāth Method of DSN-MUI Fatwa}

Because fatwas are the answer to legal problems for those who seek ${ }^{i t},{ }^{25}$ an accurate answer, then, is needed. The accuracy of the answer itself, of course, cannot be separated from the instinbath method used by the mufti, including the Istinbäth method of the DSN-MUI fatwa law.

According to the MUI Fatwa Determination Guide No. U-596/ MUI/X/1997 dated October 2, 1997, there are 4 (four) principles that are used as the basis for establishing a fatwa, namely: ${ }^{26}$ (1) Every fatwa decision must have a basis on the Qur'an and the Sunnah, and does not conflict with the benefit of the people. This means that all fatwa stipulations must rely on the main source of the Qur'an and Sunnah, and in line with general benefit. (2) If the legal provisions are not found in the Qur'an and the Sunnah of the Apostles, then the fatwa decision should not conflict with Ijm $\vec{a}$, authoritative Qiyas, including other legal arguments, such as istihsān, mashlahah mursalah, and sadd al-dzarī ah. ${ }^{27}$ "Thus, ra'yu (reasons) legal arguments also have a place in the process of determining the law. (3) Before the fatwa decision is made, the opinions of the Ulema of the previous school, both relating to the arguments of law and relating to the argument used by different parties must be explored first. If not materially, it can also be through an analogy of material laws to find the same illat. So, in this way, the MUI fatwa issued is as far as possible parallel with the opinion of the Islamic scholars, at least methodologically, (4) If it is not found as well, then the views of experts in the problem areas in fatwa decisions can be adopted and considered as material in determining the law of the case. The latter will be evident in the process of establishing fatwas on contemporary issues, especially related to the dynamics of science and technology, such as the establishment of cloning, abortion, female circumcision, organ transplantation, and the determination of halal food and beverage fatwa.

Every issue discussed at the fatwa commission (including fatwa on

${ }^{25}$ Himpunan Fatwa Keuangan Syariah Dewan Syariah Nasional MUI, p. 7.

${ }^{26}$ Guidelines for the Determination of Fatwa stipulated based on the Decree of the Indonesian Ulema Council Council No. U-596 /MUI/X/1997 dated October 2, 1997

${ }^{27}$ Himpunan Fatwa Keuangan Syariah Dewan Syariah Nasional MUI, p. 4. 
sharia economics) always relies on the Qur'an, Sunnah, Ijmä, and Qiyās. For problems that have a clear legal status through the qath'ì text, the MUI conveys it as stated in the text. While in the case of khiläfyah or differences of opinion among the schools, the determination of the fatwa is done by finding common ground through the method of aljam'u wa al-tawfiq between the opinions of the school. Before the fatwa is established, the Imam's opinion on the matter to be reported along with its arguments are to be examined closely. ${ }^{28}$ If the attempt to find a meeting point between the schools of thought is not successful, then the determination of the fatwa is based on the results of the tarjîh (choosing one opinion that is considered stronger) through the method of muqâranah al-madzâhib (comparison of law schools) by using the rules of al-figh almuqäran. (Islamic comparative law). The foundation (makhärij fiqhiyah) or legal solutions used in the fatwa determination process include; at-Taysir al-Manhäji, Tafrìq al-Halāl 'an al-Harām, I'ädah al-Nadhar, and Tahqīq al-Manāth. ${ }^{29}$ The main principles that are used as a reference in the determination of the fatwa, are: (1) Fatwa related to the main problem of faith and religion which is determined by the Qath' Nash (definite) approach, should be considered ijbāry (obligatory) (2) Religious fatwa on problems in majāl al-ikhtiläf (dissenting opinions) are categorized as facultative and ikhtiyār (endeavor); (3) Differences that are outside the majāl al-ikhtiläf are not categorized as differences, but rather as deviations. ${ }^{30}$

In determining fatwas in the field of sharia economics, DSN MUI uses thoriqoh bayaniyah, thoriqoh qiyäsiyah, and thoriqoh istishlähiyah by always referring to fiqh and ushül fiqh books and legislation in Indonesia. There are at least two covenant models that are modified according to the rules of fiqh and ushül fiqh and the laws and regulations in Indonesia. through the DSN fatwa, namely (1) modifying and merging contracts to meet community needs. (2) Perform other contracts (al-uqǜd al-

${ }^{28}$ A. Dimyati, dkk, Rekonstruksi Metodologi Fatwa Perbankan Syariah (Pati: CSIF Sekolah Tinggi Agama Islam Mathali'ul Falah, 2015), pp. 108-13.

${ }^{29}$ Ma’ruf Amin, 'Solusi Hukum Islam (Makhārij Fiqhiyah) Sebagai Pendorong Arus Baru Ekonomi Syariah di Indonesia' (presented at the Orasi llmiyah Kementrian Agama UIN Maulana Malik Ibrahim, Malang, 2017), p. 7.

${ }^{30}$ Hanif Luthfi, p. 153. 
muta'addidah), in addition to the first contract because one of the parties cannot carry out the first contract due to certain things.

\section{Legal Status of DSN MUI Fatwa in the National Legal System}

To find out the position of fatwa in a legal system, it is necessary to know in advance the trends/models of state administration law adopted in the country. This is because the differences in the constitutional law adopted by a nation will affect the position and function of the fatwa itself. ${ }^{31}$ In countries that place Islamic Shari'a as basic law and implement it fully and perfectly, the fatwa will be a binding legal decision. Whereas in secular countries (apart from religious elements), the fatwa does not have any function and position. But some countries combine secular law with Islamic law, like Indonesia, so here the fatwa has a function but is limited to the realm of Islamic law an sich. ${ }^{32}$

Isa Ansori, ${ }^{33}$ after examining the position of fatwa in several Muslim countries (Malaysia, Brunei Darussalam, and Egypt), concluded that the fatwa had a different legal position between one Muslim country and another Muslim country. This difference is influenced by the legal system and government system adopted by each country.

In Indonesia, five types of sources are used as a basis for making/ applying the law, namely: laws, customs, judges' decisions (treaties), treaties, and doctrines (opinions of legal experts). ${ }^{34}$ From the five sources of law, certain definitions that are often used as references for judges in deciding cases $\operatorname{are}^{35}: 1$ ) legal values and norms that live as unwritten constitutions; 2) certain normative habits which are recognized in normal legal traffic; and 3) doctrines of legal science that have been recognized

${ }^{31}$ Ahyar Ari Gayo, Penelitian Hukum Tentang Kedudukan Fatwa MUI dalam Upaya Mendorong Pelaksanaan Ekonomi Syariah (BPHN PUSLITBANG, 2011), p. 265.

${ }^{32}$ M. Cholil Nafis, Teori Hukum Ekonomi Syariah (Jakarta: UI Press, 2011), p. 3.

${ }^{33}$ Isa Ansori, 'Kedudukan Fatwa di Beberapa Negara Muslim', Analisis, 3.1 (2017).

${ }^{34}$ M. Erfan Riadi, 'Kedudukan Fatwa Ditinjau dari Hukum Islam dan Hukum Positif (Analisis Yuridis Normatif)', p. 474 compare to; Chainur Arrasjid, Dasar-Dasar Ilmu Hukum (Jakarta: Sinar Grafika, 2001), p. 50.

${ }^{35}$ Jimly Asshiddiqie, Pengantar Ilmu Hukum Tata Negara (Jakarta: Rajawali Pers, 2010), p. 128. Also refer to Khairuddin dan M. Iwan Satriawan, Hukum Tata Negara Pasca Amandemen UUD Negara Republik Indonesia Tahun 1945 (Jakarta: Rajawali Pers, 2018), p. 15. 
as ius comminis opinion doctorum among legal experts.

Related to the types and regulations of the laws in force in Indonesia, according to article 7 of Law Number 12 of 2011 concerning Legislation, there are 7 types of regulations in force in Indonesia, namely: the 1945 Constitution, MPR Provisions, Laws, Government Regulations Substituting for Laws, Government Regulations, Presidential Regulations, Provincial Regional Regulations, Regency/City Regional Regulations. ${ }^{36}$ From the order of the laws and regulations above it is clear that the fatwa is not mentioned as part of the legal basis in this country. So that the position of the fatwa in general, and the DSN-MUI fatwa in particular, cannot be used as a legal basis. ${ }^{37}$

According to Erfan Riadi, Fatwa is only positioned as an opinion or advice given by Islamic legal experts who are members of an organization, such as Muhammadiyah, NU, Persis, and other institutions. ${ }^{38}$ Thus, the position of the fatwa if correlated with formal legal sources in the national legal system is the same as doctrines that constitute expert opinions or the opinions of experts in the field of positive law.

Practically, doctrine (the opinion of legal experts) greatly influences the implementation of state administration, as well as in litigation. ${ }^{39} \mathrm{~A}$ judge is allowed to use expert opinion as a judge's judgment in deciding a case. Similarly, a lawyer conducting his defense in a civil case often quotes expert opinions as a reinforcement of his defense.

Related to the position of the DSN-MUI fatwa in the national legal system, Ahyar A. Gayo's research finds two different views. The first group states that the DSN-MUI fatwa has legal and binding power. The arguments they use include; (1), there is an obligation to comply with sharia principles that are stated by MUI in sharia banking activities. (2), Banks that issue new products and services must be guided by the DSN-

${ }^{36}$ Ahyar A. Gayo, Penelitian Hukum Tentang Kedudukan Fatwa MUI dalam Upaya Mendorong Pelaksanaan Ekonomi Syariah (BPHN PUSLITBANG, 2011), p. 265.

${ }^{37}$ M. Erfan Riadi, 'Kedudukan Fatwa Ditinjau dari Hukum Islam dan Hukum Positif (Analisis Yuridis Normatif)', Jurnal Ulumuddin, VI.IV (2010), p. 474.

${ }^{38}$ M. Erfan Riadi, 'Kedudukan Fatwa Ditinjau dari Hukum Islam dan Hukum Positif (Analisis Yuridis Normatif)'.

${ }^{39}$ Simonangkir dkk, Kamus Hukum (Jakarta: Sinar Grafika), p. 39. 
MUI Fatwa ${ }^{40}$. In line with that, Yeni Salma Barlinti, in her dissertation entitled "The Position of the National Sharia Council Fatwa in the National Legal System in Indonesia", quoted by Mustafa Khamal Rokan, concludes that the fatwa of the DSN MUI stands as a positive law that is binding due to the fatwa has become law in concrete and has become a reference for judges in deciding sharia economic cases in the Religious Courts. ${ }^{41}$

In contrast, the second group stated that the DSN-MUI fatwa does not have binding legal force, with the following reasons: First, the legal strength of the DSN-MUI Fatwa could only be obtained after a positivation process by the regulator. Second, there is a need for an understanding and approval from Bank Indonesia for the DSN-MUI Fatwa to be outlined in a Bank Indonesia Regulation (PBI). ${ }^{42}$ Thus, the binding legal force possessed by the DSN-MUI fatwa is not directly, but through certain stages, until it has binding legal force.

This thinking is in line with what the author has mentioned in the previous discussion, that, in general, the fatwa does not have binding legal force, including the DSN-MUI fatwa, until it is transformed into positive law. ${ }^{43}$ Fatwas can have binding legal force after being transformed into positive law and become legislation following needs. ${ }^{44}$

In terms of function, as confirmed by Shafi'i Antonio, the DSN-MUI fatwa functions to explain the law and becomes a practical regulation for financial institutions, especially when requested by practitioners of Islamic economics. Besides, it also functions as taujīh (guidance) and enlightenment to the public about sharia economic norms. The presence of these fatwas is an organic aspect of the building of Islamic economics that is being arranged/developed as well as a measurement tool for the development of Islamic economics in Indonesia. The present Sharia

${ }^{40}$ Ahyar A. Gayo, p. 59.

${ }^{41}$ Mustafa Khamal Rokan, 'Fatwa MUI dalam Tata Hukum', Surat Kabar WASPADA, 13 February 2017.

${ }^{42}$ Ahyar A. Gayo, p. 60.

${ }^{43}$ M. Erfan Riadi, 'Kedudukan Fatwa Ditinjau dari Hukum Islam dan Hukum Positif (Analisis Yuridis Normatif)'.

${ }^{44}$ M. Erfan Riadi, 'Kedudukan Fatwa Ditinjau dari Hukum Islam dan Hukum Positif (Analisis Yuridis Normatif)'. 
economic fatwa, technically, presents a model of development even the renewal of fiqh muamalah mäliyah (economic fiqh). ${ }^{45}$

\section{Implementation of DSN MUI Fatwa in Islamic Banks in Bandar Lampung}

\section{a. Historical Aspect}

The Bandar Lampung Syariah Bank, also known as the Bandar Lampung People's Financing Bank (BPRS), was established through the acquisition process by the Bandar Lampung City Government of the BPRS Sakai Sambayan. BPRS Sakai Sambaian itself is the first Sharia Bank in Lampung Province which has been operating since 1996 and was established on the initiative of Mr. Poedjono Pranyoto, the then Governor of Lampung, together with top officials within the Lampung Provincial Government, ICMI Lampung Regional Office and Lampung Province MUI.

Since its establishment in 1996, the business development of BPRS Sakai Sambayan experienced ups and downs, until in 2006 the bank began experiencing problems due to a large number of problematic financing (NPF) and less professional bank management. Since then the bank has experienced significant problems, ranging from a lack of capital adequacy (CAR) and liquidity problems which resulted in this bank becoming a bank under Special Supervision (DPK) by Bank of Indonesia.

In 2006, the Bandar Lampung City Government had plans to establish a BPR Syariah (Sharia Bank). To that end, the City Government formed a "Sharia Bank Establishment Team", in collaboration with Consultants from the Faculty of Economics of Lampung University, to conduct a study on the feasibility of the Establishment of a Sharia Bank in Bandar Lampung. From the results of the study, the team recommended 3 (three) options, namely: (1) Bandar Lampung City Market Bank was converted into a Sharia Market Bank, (2) Adding a Sharia division to the Bandar Lampung City Market Bank, or (3) Established a new bank, Bandar Lampung Syariah Market Bank.

After going through several considerations and the long process the

${ }^{45}$ Antonio Syaf'i, Bank Syariah dari Teori Ke Praktek, 1 (Jakarta: Tazkia Cendekia Gema Insani Pers, 2001). 
Sharia Bank was founded by acquiring the BPRS Sakai Sambayan, which at that time was experiencing problems. The acquisition was confirmed by the Bandar Lampung City Regulation No. 18/2008 dated September 15, 2008, concerning the Establishment of the Bandar Lampung People's Syariah Financing Bank, and continued with the issuance of the Bandar Lampung Mayor Regulation No. 91/2008 on 31 October 2008 concerning the Capital Investment of the Bandar Lampung City Government at PT. BPRS Sakai Sambayan as much as Rp. 2,957,000,000. With the capital participation of the City Government of Bandar Lampung in the amount of Rp. 2,957,000,0000, - from the total capital of all BPRS Sakai Sambayan paid by shareholders amounting to Rp. 5,000,000,000, - the value of shares owned by the Regional Government of Bandar Lampung City amounted to Rp. 3,978,500,000 (79.57\%).

The implementation of the capital participation of the Regional Government of the City of Bandar Lampung in the BPRS Sakai Sambayan is carried out through the Extraordinary RUPS of the BPRS Sakai Sambayan as stated in the Notarial Deed of Bambang Abiyono, SH. No. 20 December 5, 2008, concerning the Acquisition and Notarial Deed of Bambang Abiyono, SH. Number 21 dated December 5, 2008, concerning the Statement of the Extraordinary RUPS of the BPRS Sakai Sambayan which was approved by the Minister of Law and Human Rights on November 4, 2009.

The Extraordinary General Meeting of Shareholders' resolutions above were also approved, inter alia, (a) Increase the Company's authorized capital from Rp. 5 billion to Rp. 10 billion, (b) Changing the name of BPRS Sakai Sambayan to BPRS Lampung, (c) Relocating offices from Natar District, South Lampung Regency to Bandar Lampung City area, (d) Reorganizing the Management of the Company.

Since the acquisition process, which was subsequently followed up with the inauguration by Bank Indonesia on December 22, 2008, Bank Syariah Bandar Lampung began its operations in its new office, located at Jl. Pangeran Antasari No. 148 Bandar Lampung.

The existence of the Bandar Lampung Syariah Bank has a very promising prospect because it is the only BPR that operates with sharia 
principles in the city of Bandar Lampung. Given the public interest in Islamic banking is quite high and because the population in Bandar Lampung City is predominantly Muslim, so it becomes a potential market for developing all sharia-based activities.

\section{b. Management}

Based on the decision of the Extraordinary General Meeting of Shareholders (RUPS) on November 10, 2016, and under the Deed of Amendment to Articles of Association No. 18 made by Notary Adnan, SH. M.Kn., dated November 14, 2016, concerning the Determination of the Sharia Management Board and Supervisory Board (DPS) of the Bandar Lampung BPR Syariah, the composition of the Management and DPS of the Bandar Lampung Sharia Bank for the period of 2016-2020 are as follows; President Commissioner: A. Rahman Mustafa, M.M., Ak, Commissioner Member: Yusran Effendi, M.M. President Director: Ridwansyah, M.E.Sy, Director: Marsono, S.E, Sharia Supervisory Board: Ismail Saleh, S.H.I as chairman, and Syamsul Hilal, M.Ag as members

\section{c. Vision, Mission, and Motto}

The vision of BPR Syariah Bandar Lampung is, "To be the best Sharia BPR for economic development for UMKM and supporting development in Lampung Province". Its mission is (a) Continuously improving the knowledge and skills of Human Resources to achieve better and more reliable services, (b) Supporting community economic growth for UMKM and supporting development in Lampung Province through the services of the Sharia banking sector, (c) Growing souls entrepreneurship for UMKM based on Islamic Finance, (d) Fostering cadres of sharia-oriented entrepreneurs to become bankable and Mandiri, and (e) As one source of Regional Original Income (PAD) for the Government of Bandar Lampung City. While the BPRS motto is: "Based on Sharia, Inshallah is More Barakah".

\section{d. Ownership}

Bank Syariah Bandar Lampung, as of December 31, 2017, is owned by 3 (three) shareholders namely: Bandar Lampung City Government, 
private companies, and individuals. ${ }^{46}$ The size of the shares can be seen in the table below:

\begin{tabular}{|c|c|c|c|c|c|}
\hline \multirow[b]{2}{*}{ No. } & \multirow[b]{2}{*}{ SHAREHOLDERS } & \multicolumn{3}{|c|}{ Amount } & \multirow[b]{2}{*}{$\%$} \\
\hline & & Owner & Sheets & $\begin{array}{l}\text { Nominal } \\
\text { (Rp.000) }\end{array}$ & \\
\hline 1. & $\begin{array}{l}\text { Bandar Lampung City } \\
\text { Government }\end{array}$ & 1 & 16.957 & 8.478 .500 & 88,76 \\
\hline 2. & Private Companies & 2 & 177 & 88.500 & 0,93 \\
\hline \multirow[t]{2}{*}{3.} & Individual & 26 & 1.970 & 985.000 & 10,31 \\
\hline & TOTAL & 29 & 19.104 & 9.552 .000 & 100,00 \\
\hline
\end{tabular}

\section{e. Human Resources}

For Bandar Lampung Syariah Bank, Human Resources (SDI) is an important asset that is very instrumental in carrying out business activities. As of June 30, 2018, the number of personnel at the Bandar Lampung Islamic Bank was 33, consisting of Board of Commissioners 2 personnels, Sharia Supervisory Board 2 personnels, Directors 2 personnels, and 27 staff.

Implementation of duties for personnel of Bandar Lampung Syariah Bank is regulated by the Decree of the Directors of PT BPR Syariah Bandar Lampung No. 039/03/concerning the Organization and Work Procedure of PT BPR Syariah Bandar Lampung. As for the salary issue, Bank Syariah Bandar Lampung refers to Law No. 13 of 2003 concerning Manpower and Minister of Home Affairs Regulation No. 22 of 2006 dated 22 June 2006 concerning Management of Regional Government Owned Credit Banks, the implementation of which is governed by the Decree of the Board of Directors of the Islamic Bank of Bandar Lampung No. 042/03/ Dir-SK/UP/BL/I/ 2018 dated January 24, 2018, concerning the Principal Regulation of the Personnel of PT BPR Syariah Bandar Lampung.

To improve the ability and work skills of employees, the company provides opportunities for each employee to take part in Education and Training following their respective fields of work organized by Bank of

${ }^{46}$ Marsono, Director of BPRS Bandar Lampung, Interview on September 29, 2018. 
Indonesia, the Financial Services Authority (OJK), Perbarindo, Asbisindo, Perbamida or other institutions.

\section{f. Basic Services}

In its business activities, Bandar Lampung Syariah Bank serves the community in 3 (three) types of products, namely:

1) Savings

Types of Savings products offered at Bandar Lampung Syariah Bank consist of Savings Syariah Savings (al-Wadiah), General Sharia Savings (al-Mudhārabah), Student Savings (al-Mudhārabah), Sikencana Savings (al-Mudhārabah Savings), Hajj Savings (al-Mudhärabah), Sacrifice Savings (al-Mudhārabah), Sharia Term Deposit (al-Mudhārabah).

2) Financing

Broadly speaking, financing products offered at Bandar Lampung Syariah Bank can be distinguished in several types, namely:

(a) Financing products based on the form of the contract, including financing the sale and purchase (al-Muräbahah), Financing profit sharing (al-Mudhārabah), Financing for venture capital (alMusyārakah), Financing for leasing benefits (Ijārah Multijasa), Benevolent Financing (al-Qardh);

(b) Financing Products based on use; Working Capital (alMurābahah, al-Mudhārabah), Investment (al-Mudhārabah), Consumptive (al-Mudhārabah, al-Ijārah, Al-Qardh).

(c) Financing Products based on distribution goals; Financing for Small and Micro-Entrepreneurs (UKM), Financing for Civil Servants (PNS), Financing for BUMN, BUMD and Private Employees, Professional Teacher Certification Financing, Financing for Regional Contract Workers, Financing for BPIH, Benevolent Financing (Al-Qardh).

3) Other services

Products services include the following; Interbank funds transfer services, credit sales facilities, electricity bill payment services, services for registering the pilgrimage. Of the products offered by 
BS Bandar Lampung, the most sought after are financing products (al-muräbahah), depositary sharia savings (al-wadīah) and multiservice ijärah.

\section{g. Implementation of DSN MUI Fatwa}

According to Mr. Marsono, the director of the bank, all transactions or contracts conducted at the Bandar Lampung Syari'ah Bank have followed what was stated by DSN-MUI, which is based on sharia. ${ }^{47}$ For example in the sale and purchase financing agreement (muräbahah). According to Fatwa No. 04/DSN-MUI/IV/2000 general provisions concerning muräbahah contracts ${ }^{48}$ include:

i. Banks and customers must enter into a usury-free murābahah agreement;

ii. Goods traded are not prohibited by sharia;

iii. Banks can finance part or all of the purchase price of goods whose qualifications have been agreed;

iv. The bank buys the goods that the customer needs on behalf of the bank itself, and these purchases must be legal and free of usury;

v. The bank must submit all matters relating to the purchase if the purchase is made in debt;

vi. The bank then sells the item to the customer (the buyer) at a selling price worth the purchase price plus a profit margin. In this regard, the bank must honestly tell the cost of goods to customers along with the costs required;

vii. The customer pays the agreed price for the goods within the agreed period;

viii. To prevent abuse or damage to the contract, the bank may enter into a special agreement with the customer;

ix. If the bank wants to represent the customer to buy goods from a third party, muräbahah sale and purchase agreement must be done after the goods in principle become the property of the bank.

${ }^{47}$ Marsono, Director of BPRS Bandar Lampung, Interview on September 29, 2018.

48 Himpunan Fatwa Keuangan Syariah Dewan Syariah Nasional MUI, p. 64. 
According to the information obtained, the implementation of the Muräbahah contract at the Bandar Lampung Syari'ah Bank begins with the submission of a proposal by the customer regarding an item to be purchased along with the value or price of the item. The bank then legally purchases the ordered item from the merchant and then offers it to the ordering customer. The customer must buy it according to the promise he has agreed because it is legally binding. Furthermore, both parties make a sale and purchase contract that contains several clauses including about the down payment (if any) or the payment system (In general, customers will choose payment by installments). The bank will tell honestly the value or price of goods purchased and the amount of installments to be paid following the agreed period, as well as profit margins obtained by the bank. ${ }^{49}$

If a customer carelessly to be late in paying, then he is given a penalty in the form of a fine for late payment. This is in line with the DSN-MUI fatwa No: 17/DSN-MUI/IX/2000 which states: "People who are in debt are required to pay their debts either by installments or direct payments. For those who do not pay even though they can pay, they may be subject to sanctions in the form of fines, the amount of which is determined based on an agreement and made when the contract is signed. The fines, according to the Director of the Sharia Bank, were not put into the Bank's treasury but were channeled for social purposes such as: carrying out social service activities, fulfilling requests for assistance, orphanages, and others. ${ }^{50}$ What was done by the Bank's management was following the DSN-MUI fatwa.

Although in general it can be said that the Lampung Syari'ah Bank has followed the DSN-MUI fatwa, but there are several things done by banks that are not fully following the fatwa. For instance, in the muräbahah contract, the goods ordered by the customer sometimes have not fully become the property of the bank, in other words, it is still involved in the ownership of a third party (the owner of the goods). The DSN-MUI fatwa has determined that in a contract of buying and

\footnotetext{
${ }^{49}$ Marsono, Director of BPRS Bandar Lampung, Interview on September 29, 2018.

50 Ibid
} 
selling muräbahah goods ordered by customers at the time of the contract must, in principle, already belong to the bank.

Another example is in terms of determining the margin process. In the muräbahah process, the percentage of profit margins should be determined by the seller together with potential buyers so that there is a possibility of bargaining. However, what is practiced at Sharia Banks is the margin percentage has been determined unilaterally by the bank and the customer cannot bid or make a new agreement. ${ }^{51}$

The same is true for early repayment deductions in Murabaha. Fatwa DSN MUI requires cutting, as stated in Fatwa No. 23/DSN-MUI/III/2002: "If a customer in a murabahah transaction pays payment on time or sooner than the agreed time, the LKS may provide a deduction from the payment obligation, provided the terms are not agreed in the contract. The amount of discount referred to is left to the policy and consideration of the LKS" ${ }^{52}$ But in practice, the deduction is often not done because it was agreed from the beginning. Based on the fatwa above, the bank should have granted if the customer demanded a deduction from repayment.

\section{Conclusions}

Based on the whole description above, some conclusions can be drawn as follows, determination of DSN MUI Fatwa was issued to avoid the different provisions made by DPS in each Islamic financial institution. With the DSN MUI fatwa, the provisions governing all sharia economic actors have uniformity to create legal order. In the national legal system, the DSN MUI fatwa has become a law in concreto because it has become a reference for judges in deciding sharia economic cases in the Religious Courts, including the arbitrators in Basyarnas in resolving Islamic economic disputes.

The MUI DSN fatwa has not been fully implemented in the activities carried out by the Bandar Lampung BPRS, especially in the case of ordered goods that are not yet fully owned by the bank, the

\footnotetext{
${ }^{51}$ Rida Budiyati, a costumer, interview on Oktober 2, 2018.

${ }^{52}$ Himpunan Fatwa Keuangan Syariah Dewan Syariah Nasional MUI, p. 141.
} 
percentage of profit margins determined unilaterally by the bank, and early repayment deductions in the muräbahah contract.

\section{Acknowledgment}

This research was carried out with the help of Research Grant funds from the Office for Research and Community Service (LPPM) of the Raden Intan State Islamic University (UIN) Lampung, 2018.

\section{Bibliography}

Adam, Wahiduddinn, Fatwa Majelis Ulama Indonesia (MUI) dalam Perspektif Hukum dan Perundang-Undangan (Badan Litbang dan Diklat Kementerian Agama RI, 2012).

Amin, Marruf, 'Solusi Hukum Islam (Makharij Fiqhiyah) Sebagai Pendorong Arus Baru Ekonomi Syariah di Indonesia' (presented at the Orasi llmiyah Kementrian Agama UIN Maulana Malik Ibrahim, Malang, 2017).

Ansori, Isa, 'Kedudukan Fatwa di Beberapa Negara Muslim', Analisis, 3.1 (2017).

Arrasjid, Chainur, Dasar-Dasar Ilmu Hukum. Jakarta: Sinar Grafika, 2001. Asshiddiqie, Jimly, Pengantar IlmuHukum Tata Negara. Jakarta: Rajawali Pers, 2010.

Dimyati, A. dkk, Rekonstruksi Metodologi Fatwa Pebankan Syariah. Pati: CSIF Sekolah Tinggi Agama Islam Mathali'ul Falah, 2015.

Friedmen, Laurence W., Teori dan Filsafat Hukum : Idealisme Filosofis dan Problematika Keadilan (Sususan II ), trans. by Muhammad Arifin. Jakarta: PT. Raja Grafindo Persada, 1994.

Gayo, Ahyar A. Penelitian Hukum Tentang Kedudukan Fatwa MUI Dalam Upaya Mendorong Pelaksanaan Ekonomi Syariah. BPHN PUSLITBANG, 2011.

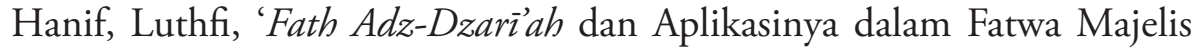
Ulama Indonesia'. Institut Ilmu Quran Jakarta, 2007.

Himpunan Fatwa Keuangan Syariah Dewan Syariah Nasional MUI. Jakarta: Erlangga, 2014.

Ifham, Ahmad, Ini Lho Bank Syariah - Memahami Bank Syariah dengan Mudah. Jakarta: Gramedia Pustaka Utama, 2015. 
Jayus, Muhammad, 'Menggagas Arah Baru Studi Hukum Islam di Indonesia', AL-ADALAH, XI.2 (2013), 258.

Khairuddin dan M. Iwan Satriawan, Hukum Tata Negara Pasca Amandemen UUD Negara Republik Indonesia Tahun 1945. Jakarta: Rajawali Pres, 2018.

M. Erfan Riadi, 'Kedudukan Fatwa Ditinjau dari Hukum Islam dan Hukum Positif (Analisis Yuridis Normatif)', Jurnal Ulumuddin, VI.IV (2010), 474.

Mahmudah, Siti, 'The Contextualization of Sharia and Its Contribution to the Development of the Indonesian National Law', Al-'Adalah, $16.1,2019$

Marsono, Director of BPRS Bandar Lampung, Interview on September 29, 2018.

Nafis, M. Cholil, Teori Hukum Ekonomi Syariah. Jakarta: UI Press, 2011. Ridwan, Murtadho, Analisis Fatwa MUI Tentang Asuransi Syariah dan Penyerapannya ke dalam Peraturan Perundang-Undangan dalam Bukti yang Bertajuk Fatwa Majelis Ulama Indonesia (MUI) dalam Perspektif Hukum dan Perundang-Undangan. Jakarta: Puslitbang Lektur dan Khazanah Keagamaan Badan Litbang dan Diklat Kementerian Agama RI, 2012.

Budiyati, Rida, a costumer, interview on Oktober 2, 2018.

Rochmiyatun, Siti, Yusida Fitriyati, 'Implementation of Arrangements for Ikrar Wakaf Land (AIW) in The Indonesian Waqf Law (Case in Palembang City)', Al-'Adalah, 16.1 (2019).

Rokan, Mustafa Khamal. 'Fatwa MUI dalam Tata Hukum', Surat Kabar WASPADA, 13 February 2017.

Syaf'i, Antonio, Bank Syariah dari Teori Ke Praktek, 1. Jakarta: Tazkia Cendekia Gema Insani Pers, 2001.

Simonangkir, dkk, Kamus Hukum. Jakarta: Sinar Grafika, 2009.

Umam, Khotibul. 'Legalisasi Fikih Ekonomi Perbankan: Sinkronisasi Peran Dewan Syariah Nasional dan Komite Perbankan Syariah', Mimbar Hukum, 24.2 (2012). 